\title{
Abraham Lincoln (I809-|865) and his teeth
}

\section{Short communication}

Abraham Lincoln was the $16^{\text {th }}$ president of the United States of America, the winner of the American Civil War, but also the $1^{\text {st }}$ assassinated President. Personal records about the former president report four visits to the dentist. It's rumoured that Lincoln had a phobia of going to the dentist. One of them was mentioned in a letter to Mary Speed, one of his sister's friends on September 27 $7^{\text {th }} 1841$. "Do you remember when I went to this city to get a tooth extracted and it totally failed? This tooth made me suffer once again so badly that a week ago, I had to have it removed, which cost me a piece of the maxilla which came out with it. My mouth is so sore that I can neither talk, nor eat. I only survive with the memory of flavours which is inadequate in terms of nutritious diet ${ }^{1}$ ". 2 visits to the dentist were needed to extract that tooth. At that time, Lincoln was staying in Louisville in Kentucky. ${ }^{2} \mathrm{He}$ developed a real apprehension towards dentistry and in particular dentists. In 1856, when he was in Milton Station (Humbolt) in Illinois, he stopped at Dr Wesley Wampler's dental office. ${ }^{3}$ There, the dentist extracted a tooth. In 1862, suffering atrociously from a toothache, he saw Dr G. Wolf whose dental office was near the church in Washington. When the dentist was about to extract a tooth, Lincoln asked him to stop. He brought out a bottle of chloroform, inhaled it several times, and before falling asleep, gave the practitioner the green light to perform his surgery. The tooth extraction occurred without pain. ${ }^{3}$ A letter written by J. Littlefield to W. Herndon on December $11^{\text {th }} 1886$, revealed that: "One night of 1862, at the White House, M. Lincoln suffered from a tooth which had been extracted. Despite the atrocious pain, he chatted with humour with, here and there; a stroke of logic which was revealing that he had understood the situation ${ }^{3}$ ".

Lincoln saw other dentists but there is no evidence of it. He was said to have visited Dr Josiah Crawford, a practitioner next to Gentryville, in Indiana, who was carrying out extractions at his patients' homes. Dr A. French reported that he had treated some members of the Lincoln's family. However, his medical charts never mentioned that he had treated the future president at his cabinet for he had only written medical charts for patients who were not paying him. ${ }^{3}$

As for his physical appearance, the autopsy report never mentioned his teeth. Furthermore, out of 119 pictures taken of Lincoln, none show his teeth. He never smiled on them. Was he too ashamed of his teeth not to show them? Two elements maintain that it was not the case. At that time, the pictures were taken with a posture which never authorised the right to smile. In addition to his presidential position with all its responsibilities, especially in war times, Lincoln was chronically depressed. He had a large lower lip and a thin upper one. Was he missing teeth? He was said to have a bump on the right cheek as well. ${ }^{3}$

Dentistry was well-developed in Washington in 1860, but that was not the case in Illinois or Indiana. Therefore, he barely saw dentists ${ }^{3}$. He was said to have good teeth. He grew up near water holes in Indiana and Kentucky which had a very high concentration of fluoride $(>1 \mathrm{ppm})$. As for his oral hygiene, he was seen buying a tooth brush in June 1843 and another, on May $18^{\text {th }} 1853$. In 1862, the New York Times published an advertisement about a tooth paste which had been approved by Mrs Lincoln while she was at the White House. ${ }^{3}$ It was standard practice for the time.
Volume 9 Issue I - 2018

\author{
Xavier Riaud \\ Department of History of Sciences and Techniques, France
}

Correspondence: Xavier Riaud, Department of History of Sciences and Technics, Laureate and Associate member of the National Academy of Dental Surgery, Free member of the National Academy of Surgery, 145, route de Vannes, 44800 Saint Herblain, France, Email xavier.riaud@wanadoo.fr

Received: October 20, 2017 | Published: January 16, 2018

Lincoln rarely ate and his food diet never contained sugars responsible for decays. He ate without frugality. Desserts never really tempted him. He neither smoked nor drank. In short, his diet never contained cariogenic food. ${ }^{3}$

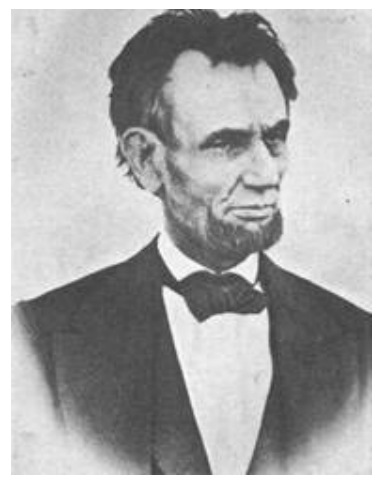

President Abraham Lincoln (1809-1865).

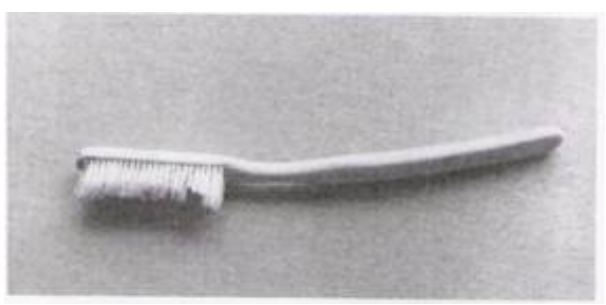

Toothbrush used by soldiers in the war. ${ }^{4}$

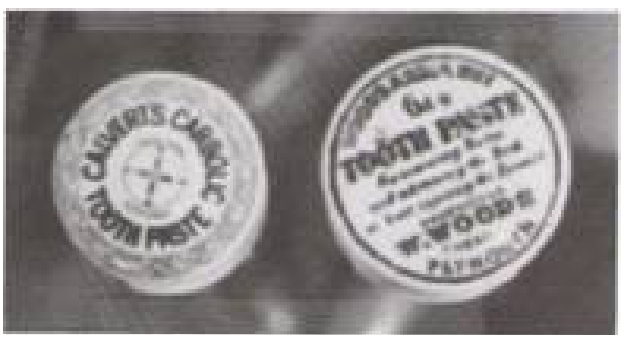

Toothpaste (1864). ${ }^{5}$ 


\section{Funding details}

None.

\section{Acknowledgments}

None.

\section{Conflicts of interest}

The author declares that there is no conflict of interest.

\section{References}

1. Norton RJ. Abraham Lincoln Personal Data and Trivia. Abraham Lincoln Research Site: USA; 2012. 1-12 p.
2. Gary Ralph Following Lincoln's Footsteps. $1^{\text {st }}$ ed. USA: Carroll \& Graf; 2001. 227 p.

3. Hine MK. The Dental Problems of Abraham Lincoln. Bull Hist Dent. 1974;2(1):1-8.

4. Sotos John G. The Physical Lincoln: Finding the Genetic Cause of Abraham Lincoln's Height, Homeliness, Pseudo-Depression, and Imminent Cancer Death. The Health and Medical History of the President Abraham Lincoln, Mt. Vernon Book Systems: USA; 2008. 1-9 p.

5. Dammann Gordon. Pictorial Encyclopedia of Civil War Medical Instruments and Equipments. USA: Pictorial Histories Publishing Company; 1988. 77-83 p. 